BBA 65434

SEED GERMINATION STUDIES

\title{
II. PATHWAYS FOR STARCH DEGRADATION IN GERMINATING PEA SEEDLINGS
}

RICHARD R. SWAIN* AND EUGENE E. DEKKER

Department of Biological Chemistry, The University of Michigan, Ann Arbor, Mich. (U.S.A.)

(Received January Ioth, I966)

SLMMARY

Amylase activity is present in extracts of the axis tissue of etiolated pea seedlings. Several lines of evidence establish that this starch-hydrolyzing activity is due to the presence of a $\beta$-amylase ( $\alpha$-I,4-glucan maltohydrolase, EC 3.2.I.2); the properties of this enzyme are reported. Maltase (EC 3.2.I.20) activity is also present in extracts of the same tissues. Since $\alpha$-amylase (EC 3.2.I.I) activity appears in the germinating cotyledon, the following hydrolytic pathway for the degradation of starch to glucose is present in the pea seedling:

$$
\operatorname{starch} \stackrel{\alpha \text {-amylase }}{\longrightarrow} \text { oligosaccharides } \stackrel{\beta \text {-amylase }}{\longrightarrow} \text { maltose } \stackrel{\alpha \text {-glucosidase }}{\longrightarrow} \text { glucose }
$$

The importance of this pathway is considered in relation to the alternative route for starch catabolism, namely, the phosphorolytic pathway involving the enzyme phosphorylase (EC 2.4.I.I).

\section{INTRODUCTION}

In mammals, glycogen is the storage polysaccharide of liver and muscle tissue. At present, two rather different enzymic routes for glycogen breakdown, at least in liver tissue, have been elucidated. The one involves the so-called "phosphorylase pathway" for glucose production and requires a sequential participation of the enzymes phosphorylase (EC 2.4.I.I), phosphoglucomutase (EC 2.7.5.I), and glucose6-phosphatase (EC 3.I.3.9) (ref. I). More recently, RUTTER AND BRosemer ${ }^{2}$ reported another route for glucose formation from glycogen in liver. In this instance, soluble oligosaccharides are first formed by the action of an $\alpha$-amylase (EC 3.2.1.I) on glycogen. Subsequently, these oligosaccharides are hydrolyzed by a-glucosidase (mal-

"Recipient of a National Science lioundation Cooperative Graduate Fellowship (r963I964) and a Graduate School Predoctoral lellowship, The University of Michigan (1964-1965). 
tase) activity ( $\mathrm{EC}$ 3.2.1.20) with the release of free glucose. These two routes can most simply be referred to as the "phosphorolytic" and the "hydrolytic" pathways.

For plants and especially the cotyledonous seeds, starch is the corresponding form of storage polysaccharide that is synthesized and reserved in the form of starch granules. In the preceding paper ${ }^{3}$, we presented evidence for the presence of an amylase of the $\alpha$-type in extracts of germinated pea cotyledons. In these studies, we never observed the accumulation of any significant amount of free glucose in the cotyledon nor was there any detectable $\alpha$-amylase activity in extracts of the axis tissue of the growing pea seedling. Phosphorylase activity, however, has previously been found in pea seeds by HANEs ${ }^{4}$, but the level of this activity throughout the process of germination is unknown. Metabolic pathways whereby starch is catabolized to the level of free glucose by plants also have not been examined in any detail. Since both $a$-amylase and phosphorylase activity arc present in extracts of the pea cotyledon, one might first suggest that the function of the $a$-amylase is to accelerate the phosphorolytic reaction. However, a participation of the $a$-amylase in a completely hydrolytic pathway for starch degradation, analogous to the route for glycogen breakdown in mammals, must also be considered.

The present report, therefore, is concerned with the biochemical role of the $a$ amylase and other carbohydrases in pea seed germination. Evidence is provided for the presence in intact pea seedlings of $\beta$-amylase $(\alpha-\mathrm{I}, 4$-glucan maltohydrolase, EC 3.2.I.2), maltase ( $\alpha$-glucosidase), amylopectin-1,6-glucosidase (EC 3.2.I.9), phosphorylase, and sucrase (EC 3.2.I.26) activity in either the cotyledon, axis tissue, or both. The results indicate that a "hydrolytic" as well as a "phosphorolytic" sequence of reactions represent significant pathways for glucose formation from starch in the developing pea plant.

MATERIAIS AND METHODS

[1-14C Maltose (specific activity, I.2I mC/mmole) and uniformly-labeled $\mathrm{D}$ $\left.{ }^{14} \mathrm{C}\right]$ glucose (specific activity, $30 \mathrm{mC} / \mathrm{mmole}$ ) were purchased from Calbiochem, Inc., Los Angeles, California (U.S.A.). The presence of radioactive materials on paper chromatograms was detected with the use of a Vanguard Autoscanner 880 obtained from Vanguard Instrument Co., LaGrange, Illinois (U.S.A.).

Amylase activity $\left(\alpha\right.$ or $\beta$ ) was routinely measured as described previously ${ }^{3}$. This assay procedure, as used, shows proportional accumulation of reducing products with increasing times of incubation and with increasing concentrations of protein. The specific activity of amylase preparations is defined as mg of maltose liberated per ro min per $\mathrm{mg}$ protein ${ }^{3}$.

Peas were germinated as reported earlier ${ }^{3}$.

$\beta$-Limit dextrin was prepared by incubating Io $\mathrm{mg}$ of a commercial $\beta$-amylase preparation with ro $\mathrm{ml}$ of a $2 \%$ soluble starch solution in $0 . \mathrm{I} \mathbf{M}$ acetate buffer $(\mathrm{pH} 5.8)$ at $37^{\circ}$. When the starch-iodine color (determined by adding $0 . \mathrm{I}-\mathrm{ml}$ aliquots of the incubation mixture to $5 \mathrm{ml}$ of a $0.25 \mathrm{M} \mathrm{KI}-0.0035 \mathrm{M} \mathrm{I}_{2}$ solution ${ }^{2}$, diluting to I5 $\mathrm{ml}$ with $\mathrm{H}_{2} \mathrm{O}$, and reading in a Klett-Summerson photoelectric colorimeter equipped with a No. 54 filter) decreased to a constant value, a $\beta$-limit dextrin was assumed to have been formed. This preparation was used for measuring debranchingenzyme activity without inactivation of the $\beta$-amylase.

Biochim. Biophys. Acta, 122 (1966) 87-100 
Phosphorylase was assayed as described by WHELAN ${ }^{5}$. Activity values for this enzyme are expressed in $\mathrm{mg}$ of inorganic phosphorus liberated in Io min at $35^{\circ}$.

Special soluble starch solution for use in optical rotation studies was prepared as described before ${ }^{3}$; the sources of known $\alpha$ - and $\beta$-amylases as well as of various oligosaccharide standards for use in paper chromatographic techniques have also been listed in the preceding paper $^{3}$. Glucostat, a commercial reagent containing glucose oxidase (EC I.I.3.4), peroxidase (EC I.II.I.7), and a chromogen, was the source of glucose oxidase and was purchased from the Worthington Biochemical Corp., Freehold, New Jersey (U.S.A.). All other reagents were commercial products.

Protein concentrations were determined by the method of LownY et al. ${ }^{6}$ with crystalline bovine serum albumin as the standard.

\section{Preparation of $\beta$-amylase from extracts of axis tissue}

All operations were performed at $4^{\circ}$ unless indicated otherwise. $\beta$-Amylase preparations were made routinely by grinding pea-seedling stems (not including the first true leaves) from 7 to ro-day-old plants in a mortar and pestle with $0.05 \mathrm{M}$ acetate buffer $(\mathrm{pH} 6.0)$ containing 0.00I M EDTA and $0.005 \mathrm{M}$ 2-mercaptoethanol. $\mathrm{I} \mathrm{ml}$ of buffer solution was used for each $2 \mathrm{~g}$ of tissue (wet weight). The resulting homogenate was strained through cheese cloth and then centrifuged at $18000 \times g$ for Io min. Crystalline ammonium sulfate $(2.3 \mathrm{~g} / \mathrm{Io} \mathrm{ml}$ of fluid) was added slowly to the soluble extract with constant stirring. After complete addition of the salt, the solution was stirred for an additional $30 \mathrm{~min}$. The precipitated protein was removed by centrifugation and discarded. More crystalline ammonium sulfate was added as before to the resulting supernatant fluid until a final concentration of $5.3 \mathrm{~g} / \mathrm{I} 0 \mathrm{ml}$ of original extract was obtained. The precipitate now removed by centrifuging was dissolved in a small volume (I-IO ml) of $0.025 \mathrm{M}$ acetate buffer ( $\mathrm{pH}$ 5.4) and dialyzed against $\mathrm{I} l$ of the same buffer for $8 \mathrm{~h}$. After dialysis, the enzyme solution was centrifuged a second time to remove insoluble material. The supernatant fluid, containing the $\beta$-amylase activity, had a protein concentration of 1.0 to $2.0 \mathrm{mg} / \mathrm{ml}$ of solution and a specific activity of 9 to 20 as compared to 2 to 4 for the orginal extract.

RESULTS

Identification of $\beta$-amylase activity in pea seedling axis tissue

When extracts of the axis tissue of pea seedlings were tested for amylase activity with soluble starch as substrate, reducing compounds were liberated. No activity remained, however, when these extracts were heated for $15 \mathrm{~min}$ at $70^{\circ}$ in the presence of added calcium ions. In addition, this starch-hydrolyzing activity remained fully active after dialyzing for prolonged periods of time against $5 \cdot 1 \mathrm{O}^{-3} \mathrm{M}$ (final concentration) EDTA. These properties of the amylase activity present in $\mathrm{cx}$ tracts of axis tissue are in direct contrast with the $a$-amylase activity detected in extracts of germinating pea cotyledons ${ }^{3}$. The following evidence is presented as proof that the amylase activity of axis tissue is of the $\beta$-type.

I. As indicated above, the enzyme is completely inactivated by heating in the presence of $\mathrm{Ca}^{2+}$ and retains full activity in the presence of EDTA.

II. When the enzyme is incubated with soluble starch as substrate, maltose is 
the only low-molecular-weight reducing sugar formed. This was shown as follows. A $\beta$-amylase preparation $(0.4 \mathrm{mg}$ protein, specific activity $=$ I9) was incubated with $1.0 \mathrm{ml}$ of a $3 \%$ soluble starch solution for $60 \mathrm{~min}$ at $37^{\circ}$. The reaction was stopped by placing the incubation tubes in a boiling-water bath for $5 \mathrm{~min}$; I $\mathrm{ml}$ of the incubation mixture was subsequently added to I $\mathrm{ml}$ of absolute ethanol. After the precipitate of undigested starch and denatured protein was removed by centrifugation, $20-\mu l$ and $40-\mu l$ samples of the supernatant fluid were applied to sheets of Whatman No. I filter paper. The chromatograms were developed either in a solvent system consisting of $n$-butanol-pyridine-water $(6: 4: 3, v / v)$ for 2 I h or in $75 \%$ isopropyl alcohol for $33 \mathrm{~h}$. Descending solvent flow was used; reducing substances were detected on the chromatograms by use of a benzidine-periodate reagent? ${ }^{\text {. Without }}$ exception, only one spot corresponding in $R_{\boldsymbol{F}}$ value with known maltose is seen in samples obtained from the enzymic incubation mixture. When commercial samples of known enzymes were tested under the same conditions, $\beta$-amylase liberated only maltose whereas glucose, maltose, maltotriose, and maltotctraosc were detected in digestion mixtures containing $\alpha$-amylase.

\section{TABLE I}

\section{STARCH Digestion By AMYLASE ACTIVITy OF PEA SEEDLING AXIS TISSUE}

Enzymic activity was followed by the disappearance of the starch-iodine color complex. The incubation mixtures contained $2.0 \mathrm{ml}$ of a I \% soluble potato starch solution in $0 . \mathrm{I} \mathrm{M}$ acetate buffer $\left(\mathrm{pH}_{5} .8\right)$ and the following amounts of each amylase preparation: known bacterial $\alpha$-amylase, $0.4 \mathrm{mg}$; known $\beta$-amylase from barley malt, $0.6 \mathrm{mg}$; enzyme preparation from pea seedling axis tissue, $0.5 \mathrm{mg}$ protein (specific activity - I9). The final volume was adjusted to $3.0 \mathrm{ml}$ by adding distilled water. While the reaction mixtures were incubated at $25^{\circ}, 0 . \mathrm{I}-\mathrm{ml}$ aliquots were removed at the times indicated and added to $5 \mathrm{ml}$ of an iodine solution $\left(0.25 \mathrm{M} \mathrm{KI} \mid 0.003 .5 \mathrm{M} \mathrm{I}_{2}\right.$ (ref. 2)). The resulting solution was diluted with Io $\mathrm{ml}$ of water, mixed, and read against a reagent blank in a Klett-Summerson photoelectric colorimeter equipped with a No. 54 filter.

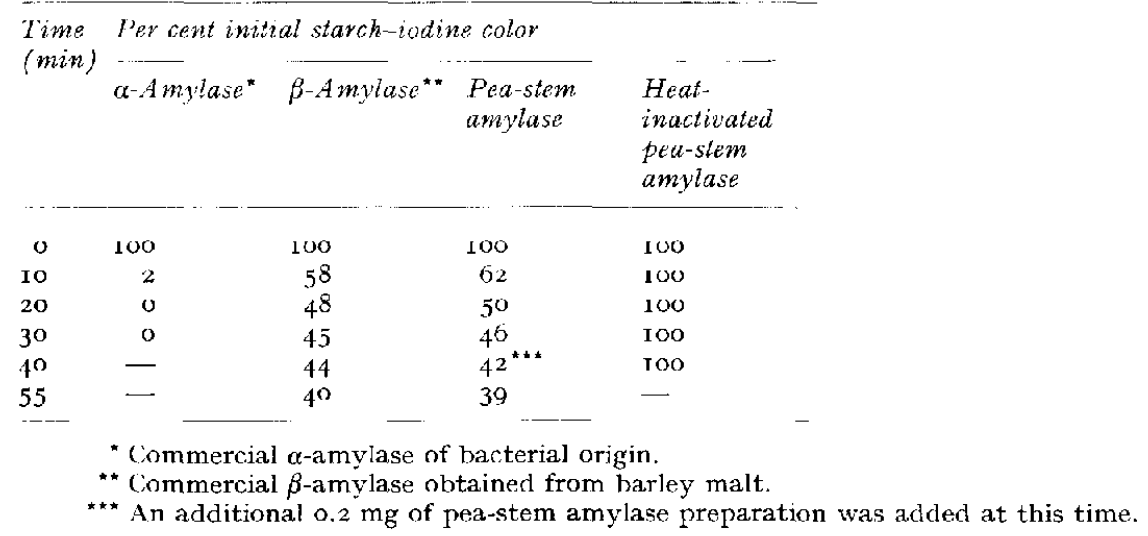

III. The formation of a $\beta$-limit dextrin is observed when the pea-stem amylase is incubated with a soluble starch solution. (Table I). The failure of this enzyme to digest starch with complete disappearance of the starch-iodine color is characteristic of known $\beta$-amylases ${ }^{8}$ and reflects the inability of these enzymes to bypass $\alpha-1,6-$ glucosidic linkages.

IV. The maltose released in an incubation mixture containing the ped-stem enzyme and soluble starch solution has the $\beta$-configuration at the anomeric carbon 


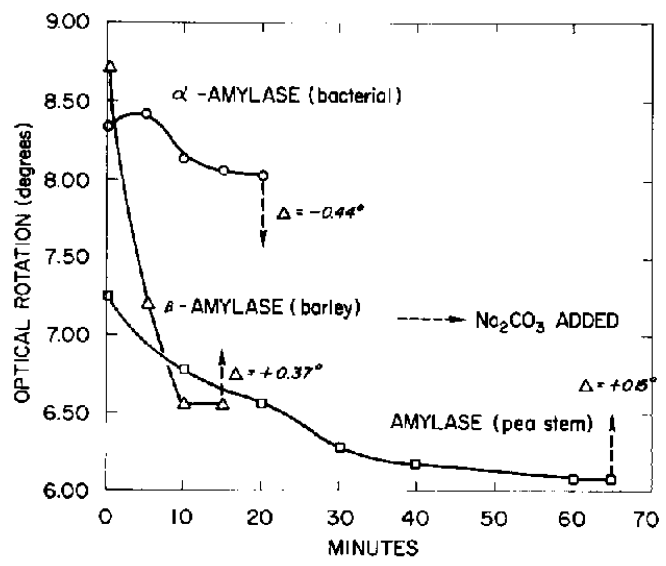

Fig. I. Optical rotation study of the action of amylases. A polarimeter tube (2.2 dm in length; fluid capacity of $\mathrm{r} 8 \mathrm{ml}$ ) was filled with a $2 \%$ solution of soluble starch (free of opalescence). Peastem amylase was prepared as described in the text from $70 \mathrm{~g}$ of frozen 7 -day-old stems; protein concentration $=1.2 \mathrm{mg} / \mathrm{ml}$ (specific activity $=20$ ). The designated amylase was added in the following amounts: pea stem enzyme, $2.4 \mathrm{mg}$ of protein; commercial $\alpha$-amylase (from bacteria), $5.0 \mathrm{mg}$; commercial $\beta$-amylase (from barley malt), $5.0 \mathrm{mg}$. $\Lambda$ fter the polarimeter readings reached a relatively constant value, Io mg of sodium carbonate were added and the direction and magnitude of change in optical rotation observed (shown by arrows).

atom. When an amylase digests a soluble starch solution contained in a polarimeter tube, the subsequent addition of $\mathrm{Na}_{2} \mathrm{CO}_{3}$ rapidly catalyzes the process of mutarotation in a rotational direction that is characteristic of the configuration of the sugar(s) released by the enzyme (see the preceding paper for a more detailed explanation of this process). The results obtained with preparations of known $\alpha$ - and $\beta$-amylases as well as of the pea-stem amylase (Fig. I) show that with the latter enzyme an increase in optical rotation value is observed.

Collectively, these findings establish that the starch-hydrolyzing enzyme present in extracts of the stem of pea seedlings is an amylase of the $\beta$-type.

Distribution zeithin the seedling. To determine the pattern of distribution of $\beta$ -

\section{TABLE II}

Distribution of $\beta$-AMYlase in PEa axis tissue

Etiolated plants (germinated 9 days) with stem lnegth of $15 \mathrm{~cm}$ and root length of $9 \mathrm{~cm}$ or more were used. The measurements listed for cach section were made starting from the cotyledon and proceeding toward the growing tip of the stem or root, respectively. Amylase activity is expressed as $\mathrm{mg}$ of maltose liberated per 10 min per $\mathrm{g}$ wet wt. of tissue.

\begin{tabular}{lcl} 
Tissue & $\begin{array}{l}\text { Section } \\
(\mathrm{cm})\end{array}$ & $\begin{array}{l}\beta \text {-Amylase } \\
\text { activity } \\
\text { (mg maltose/g } \\
\text { zet tissue) }\end{array}$ \\
\hline \multirow{3}{*}{ Stem } & $0-5$ & 4.8 \\
& $5-10$ & 11.1 \\
& 10-15 & 3.3 \\
Root & 0-5 & 2.7 \\
& $5-$ tip & 4.9 \\
\hline
\end{tabular}


amylase activity in axis tissue, 9-day-old etiolated seedlings were sectioned and extracts of each segment tested for enzymic activity. The results listed in Table II show that the enzyme is located throughout the entire length of the stem and root but not necessarily uniformly. It appears that a small amount of $\beta$-amylase activity is also present in the cotyledon. When dry pea seeds are allowed to imbibe water for a few hours, extracts of these swelled seeds display amylase activity which is destroyed by heating at $70^{\circ}$ for $15 \mathrm{~min}$ in the presence of added calcium ions. This activity is not inactivated by prolonged dialysis against $5 \cdot 10^{-3} \mathrm{M}$ EDT $\Lambda$. Indications are, therefore, that the earliest detectable starch-hydrolyzing activity present in pea seeds is due to a $\beta$-amylase. Even throughout 8 to so days of germination, a small but constant amount of this type of amylase activity is always present in cotyledon extracts. In contrast, $\alpha$-amylase activity stable to heat treatment and inactivated by EDTA (ref. 3 ) is not present in cotyledon extracts until the third day of germination; it is this cnzymic activity which increases manifold after the third day.

All of the amylase activity present in the axis tissue, however, is of the $\beta$ type. In summary, therefore, $\alpha$-amylase activity is restricted to the cotyledon whereas the $\beta$-amylase is present in constant small amounts in the cotyledon and also appears in the growing axis tissue. This distribution of $\beta$-amylase activity in the pea is quite different from that found for the cereal grains where the ungerminated seeds are a good source of this enzyme ${ }^{9}$.

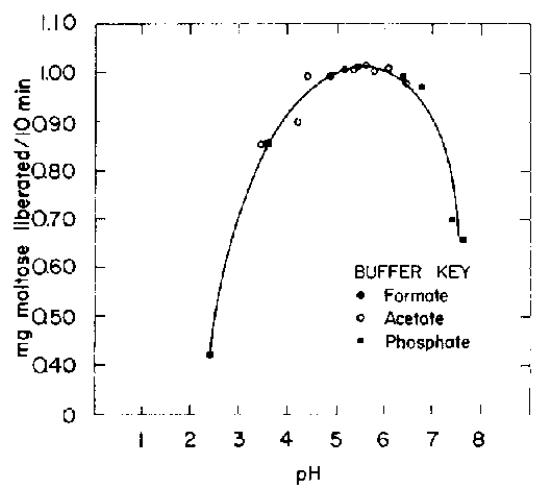

Fig. 2. Activity of amylase from pea axis tissue as a function of $\mathrm{pH}$. The amylase (o, 2 mg protein), prepared from 9 -day-old seedlings (specific activity -9.1 ), was added to each of several tubes containing $10 \mathrm{mg}$ of soluble starch and $\mathrm{I} .0 \mathrm{ml}$ of $0.2 \mathrm{M}$ buffer solution of the desired $\mathrm{pH}$ value. The final incubation vol. was $2.0 \mathrm{ml}$. The $\mathrm{pH}$ of the solution in each tube was measured with the use of glass electrode (points plotted) before adding the enzyme. After incubating the tubes for Io $\mathrm{min}$ at $25^{\circ}$, the enzymic reaction was stopped by adding $2 \mathrm{ml}$ of 3.5 -dinitrosalicylic acid reagent. All results were corrected for any reducing material found in a control tube in which the 3,5-dinitrosalicylic acid reagent was added at zero time.

$p H$ dependence of enzyme activity. The effect of $\mathrm{pH}$ on enzymic activity was determined using o.I $\mathrm{M}$ formate, o.I $\mathrm{M}$ acetate, and $\mathrm{o}$.I $\mathrm{M}$ phosphate buffer solutions to cover the $\mathrm{pH}$ range, $2.5-7.7$. The $\beta$-amylase from pea stems shows maximal activity in the $\mathrm{pH}$ range $5.2-6 . \mathrm{I}$ ( $\mathrm{Fig} .2) ; \mathrm{pH}$ optima values of this order of magnitude are typical for $\beta$-amylases found in various plants ${ }^{9}$. 
Determination of activation energy $\left(E_{a}\right)$. The activation energy of the reaction catalyzed by the $\beta$-amylase was determined from an Arrhenius plot covering the temperature range, $18.7^{\circ}-39.9^{\circ}$. A straight line is obtained in such a plot and the value of $E_{\mathrm{a}}$ calculated from the slope of the line is $9900 \mathrm{cal} / \mathrm{mole}$. The corresponding value determined over the same temperature range for the $\beta$-amylase of wheat is $9300 \mathrm{cal} / \mathrm{mole}$ (ref. Io).

Inhibition studies. Various types of reagents that react with sulfhydryl groups present in protein molecules act as inhibitors of the $\beta$-amylase activity of pea seedlings (Table III). This property appears to be general for $\beta$-amylases prepared from a variety of different sources ${ }^{9}$. No loss of $\beta$-amylase activity is observed when the enzyme is dialyzed exhaustively against EDTA or other calcium-ion binding reagents.

\section{TABLE III}

\section{INHIBITION OF $\beta$-AMYLASE ACTIVITY}

The enzyme was prepared as described in the text, except that 2-mercaptoethanol was omitted from the buffer soltion used to extract the activity from axis tissue; the specific activity of the preparation $=$ I8.0. Enzyme protein $(63 \mu \mathrm{g})$, acetate buffer $(\mathrm{pH} 5.8,90 \mu$ moles $)$, and the individual inhibitor at the concentration listed, in a final volume of r.o ml, were subjected to a prior incubation for $1.5 \mathrm{~min}$ at $25^{\circ}$. Thereafter, $1 \mathrm{ml}$ of a $\mathbf{I} \%$ soluble starch solution in o. $\mathrm{I}$ M acetate buffer ( $\mathrm{pH}$ 5.8) was added to each tube and the standard assay carried out. Separate tests showed that these inhibitors had no effect on the colorimetric determination using 3,5-dinitrosalicylic acid reagent.

\begin{tabular}{|c|c|c|}
\hline Reagent & $\begin{array}{l}\text { Concn. } \\
(M)\end{array}$ & $\begin{array}{l}\text { Enzyme activity } \\
\text { (\% of control) }\end{array}$ \\
\hline None & - & IOO \\
\hline $\mathrm{Hg}\left(\mathrm{CH}_{3} \mathrm{COO}_{2}\right.$ & $I \cdot 1 O^{-6}$ & 45 \\
\hline $\mathrm{Hg}\left(\mathrm{CH}_{3} \mathrm{COO}\right)_{2}$ & $I \cdot \mathbf{I O}^{-\mathbf{B}}$ & 0 \\
\hline $\mathrm{AgNO}_{3}$ & $1 \cdot 10^{\cdots 5}$ & 0 \\
\hline РСMB & $I \cdot I O^{-6}$ & 86 \\
\hline PCMB & $\mathbf{I} \cdot \mathbf{I} \mathbf{O}^{-5}$ & 0 \\
\hline
\end{tabular}

\section{Metabolic role of the $\beta$-amylase}

The presence of an $\alpha$-amylase in the storage organ (cotyledon) and of a $\beta$ amylase primarily in the axis tissue poses the question as to what the physiological function of these two enzymes may be in the pea scedling. If maltase ( $\alpha$-glucosidase) activity is also present in axis tissue, starch breakdown to glucose can occur in the intact seedling by a simple hydrolytic pathway, as illustrated in the following sequence of reactions:

$$
\operatorname{starch} \stackrel{\alpha \text {-amylase }}{\longrightarrow} \text { soluble } \text { oligosaccharides } \stackrel{\beta \text {-amylase }}{\longrightarrow} \text { maltose } \stackrel{\alpha \text {-glucosidase }}{\longrightarrow} \text { glucose }
$$

In other words, starch granules in the cotyledon are hydrolyzed with the formation of soluble oligosaccharides; these are then translocated to the axis tissue where the $\beta$-amylase liberates maltose. An $\alpha$-glucosidase (maltase), in turn, would yield glucose as the final product which is then metabolized via recognized routes to meet the energetic or synthetic requirements of developing plant tissues. Such a pathway is similar in some respects to that proposed by RUTTER AND BROSEMER ${ }^{2}$ as an alternate route for the formation of blood glucose from glycogen in mammals. The following studies were carried out to determine whether a completely hydrolytic 
route for starch degradation, not involving phosphorylated intermediates, is also present in plants.

\section{Maltase activity in the pea seedling}

Jono"ll first reported that dry pea seeds contain maltase activity. We tested extracts of pea axis tissue for this enzymic activity by measuring the formation of glucose from maltose (method of LAWS AND MoORE ${ }^{12}$ ). Weak maltase activity was detected. This activity depended upon the addition of substrate and of native enzyme, and roughly showed a proportional accumulation of product with increasing time of incubation and with increasing protein concentration. However, since the obscrved activity was weak $(0.3 \mathrm{mg}$ of glucose are liberated from $5 \mathrm{mg}$ of maltose per $\mathrm{h}$ ), further evidence was obtained to show more definitively that glucose is the product of the reaction.

An extract was prepared by grinding, with a pestle in a chilled mortar, freshlyharvested stems ( $52 \mathrm{~g}$, wet wt.) from 6-day-old seedlings with $20 \mathrm{ml}$ of $0.025 \mathrm{M}$ acctate buffer solution ( $\mathrm{pH} 4.6$ ) containing $2.5 \mu$ moles of EDTA and $2.0 \mu$ moles of 2-mercaptoethanol. This extract was strained through cheese cloth and subsequently dialyzed for ${ }_{5} \mathrm{~h}$ against $4 \mathrm{I}$ of the same buffer solution. Dialysis was continued for another $8 \mathrm{~h}$ against $4 \mathrm{l}$ of fresh buffer solution. The precipitate that formed during dialysis was removed by filtering through glass wool. $A$ portion $(36 \mathrm{ml})$ of the filtrate was concentrated to $3 \mathrm{ml}$ by pressure dialysis. This preparation $(0.75 \mathrm{ml} ; 0.75 \mathrm{mg}$ protein) was incubated with $5 \mathrm{mg}$ of maltose in a total volume of $0.85 \mathrm{ml}$ for $90 \mathrm{~min}$ at $37^{\circ}$; a control tube contained extract that had been boiled for 2 min. After incubating, the contents of each tube were streaked on sheets of Whatman No. 3 filter paper and the cliromatograms were developed for $\mathrm{I} 7 \mathrm{~h}$ in a solvent system consisting of $n$-butanol-pyridine- $\mathrm{H}_{2} \mathrm{O}(6: 4: 3, \mathrm{v} / \mathrm{v}$, descending solvent flow). Narrow strips, cut from the sides of the chromatograms and examined for reducing substances with the benzidine -periodate reagent ${ }^{7}$, showed two positive areas in the case of the incubation mixture containing the native enzyme. One of these bands corresponded in mobility to maltose and the other to glucose. The chromatogram of the reaction mixture containing boiled enzyme showed only one reducing substance identical in $R_{F^{\prime}}$ value with maltose. The portion of the chromatogram corresponding to glucose, for both the complete incubation mixture and the control, was eluted with water. A test of these eluates with Glucostat showed that $\mathrm{I} .2 \mathrm{mg}$ of glucose had been formed in the incubation mixture containing native enzyme but none in the reaction vessel having the boiled extract. Since glucose oxidase is a highly specific enzyme ${ }^{13}$, these findings indicate that pea axis tissue contains maltase activity.

An alternative explanation for these observations, however, is that what appears to be maltase activity is really the result of glucosyl-transfer activity ${ }^{14,15}$. This possibility was tested as follows. Pea stems ( $25 \mathrm{~g}$, wet wt.) from 9-day-old scedlings were extracted by grinding with ro $\mathrm{mI}$ of buffer solution as above; protein concentration $=0.4 \mathrm{mg} / \mathrm{ml}$. Cotyledons ( $14 \mathrm{~g}$, wet wt.) from the same seedlings were homogenized with $20 \mathrm{ml}$ of the buffer solution in a Waring blendor; protein concentration = $3.9 \mathrm{mg} / \mathrm{ml}$. Stem extract (o.I $\mathrm{mg}$ protein) and cotyledon extract (I.o $\mathrm{mg}$ protein) were incubated in separate tubes containing $\left[\mathrm{I}^{-14} \mathrm{C}\right]$ maltose (350 ooo counts/min) plus carrier maltose $\left(5.6 \mu\right.$ moles) in $20 \mathrm{mM}$ acetate buffer $\left(\mathrm{pH}_{4} .6\right)$; final volume $=$ $0.5 \mathrm{ml}$. Boiled-enzyme controls were included for each enzyme preparation tested. 
After all solutions were incubated for $60 \mathrm{~min}$ at $37^{\circ}$, the reactions were stopped by placing the incubation tubes in a boiling-water bath for I min. Denatured protein was removed by centrifugation and aliquots $(25 \mu \mathrm{l})$ of the supernatant fluids were applied to sheets of Whatman No. I filter paper together with reference samples of known glucose, maltose, maltotriose, and maltotetraose. The chromatograms were developed, by descending solvent flow for $2 \mathrm{I} \mathrm{h}$, in a solvent system containing ethyl acetate-pyridine-water (I0:4:3, v/v). Radioactive substances on the chromatograms were detected with the use of a Vanguard Model 880 Autoscanner (Fig. 3). Samples

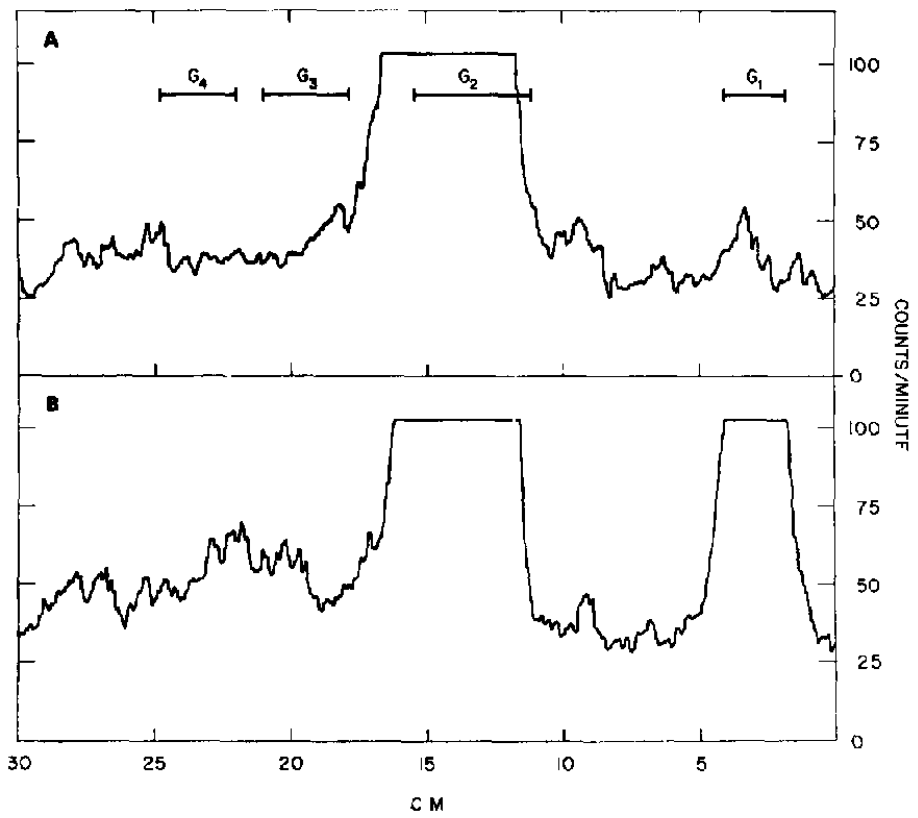

Fig. 3. Reaction products formed by pea maltase with $\left[\mathrm{I}^{\mathbf{1 4}} \mathrm{C}\right]$ maltose as substrate. A, boiled enzyme; $B$, native enzyme. $G_{1}$, glucose; $G_{2}$, maltose; $G_{3}$, maltotriose; $G_{4}$, maltotetraose.

obtained from the boiled-enzyme controls showed, in each case, the presence of only radioactive maltose. In contrast, samples obtained from reaction mixtures containing native enzyme from either axis tissue or cotyledons contained a second radioactive compound. This new radioactive substance, in each case, had the same $R_{F}$ value as known glucose. No radioactive areas corresponding to maltotriose, maltotetraose, or panose (isomaltosylglucose) were seen. When these same enzyme preparations were tested in an identical manner except in the presence of uniformlylabeled $\mathrm{D}-\left[{ }^{14} \mathrm{C}\right]$ glucose $(30 \mathrm{mM})$ and unlabeled maltose $(\mathbf{I 5} \mathrm{mM})$, no radioactive maltose was observed. In these experiments, any transfer activity in the order of 4 to $5 \%$ or greater would have been detected. When considered collectively, the results of these experiments seem to rule out the presence of any significant amount of glucosyl-transfer activity in pea seedling extracts. Rather, the liberation of glucose from maltose appears to be the result of maltase activity. The addition of inorganic phosphate did not stimulate glucose formation, suggesting that this result is also not due to the presence of maltose phosphorylase ( $\mathrm{EC}$ 2.4.I.8). 
TABLE IV

DEBRANCHING ENZYME ACTIVITY IN PEA SEEDLING EXTRACTS

Finzymic activity was followed by the disappearance of the starch-iodine color complex, as described in the legend to Table 1 . The incubation mixtures contained I.o $\mathrm{ml}$ of $\beta$-limit dextrin solution and $0.5 \mathrm{ml}$ of the respective enzyme preparation, except in the case where no extract was added. The reaction mixtures were incubated at $37^{\circ}$. Cotyledon extracts were made by homogenizing 25 cotylcdons from 6-day-old scedlings with $25 \mathrm{ml}$ of $0.1 \mathrm{M}$ acetate buffer (pH 5.9 ) in a Waring blendor. The homogenate was strained through cheese cloth and centrifuged at 18 ooo $\times$ $g$ for 20 min. EDTA $(0.1 \mathrm{M}, 5 \mathrm{ml})$ was added to every $5 \mathrm{ml}$ of the resulting supernatant fluid; final protein concentration $-3.7 \mathrm{mg} / \mathrm{ml}$. lixtracts were also made by grinding, with a pestle in a chilled mortar, 25 stems of the same seedlings in. $15 \mathrm{mi}$ of the acetate butfer listed above. No E1DTA was added in this case; final protein concentration $=2.4 \mathrm{mg} / \mathrm{ml}$. Both preparations were stored for is h at $4^{\circ}$ beforc being used. Heat-inactivated controls were made by boiling the extracts in a water bath for 2 min.

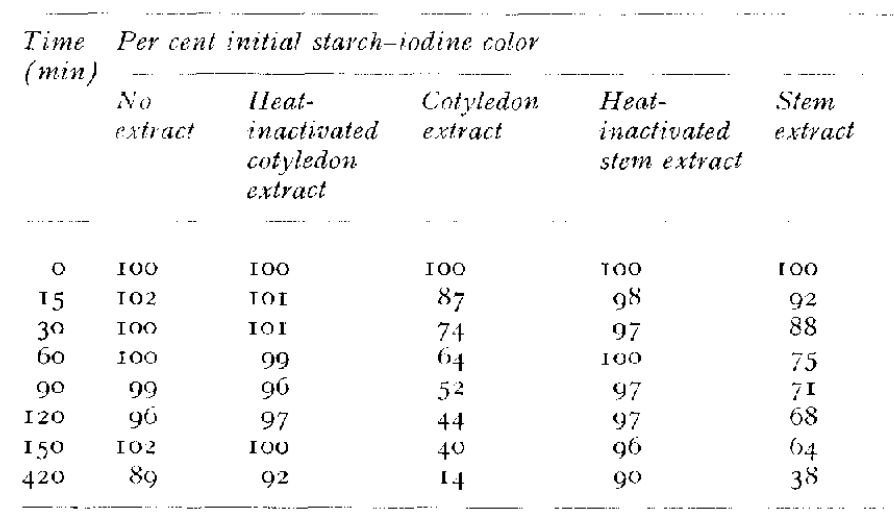

\section{Debranching activity in pea seedlings}

A completely hydrolytic pathway for starch degradation in pea seedlings denrands the participation of a debranching enzyme in addition to the $\alpha$-amylase, $\beta$-amylase, and $\alpha$-glucosidase. Such an enzyme might be an amylopectin-r,6-glucosidase (R enzyme, EC 3.2.I.9) (refs. I6, I7).

Debranching-enzyme activity was detected in extracts of both pea cotyledons and of axis tissue by measuring their ability to catalyze the degradation of a $\beta$-limit dextrin. The disappearance of the starch-iodine color complex was followed (Table IV). This activity is heat labile and non-dialyzable. However, since the use of a $\beta$-limit dextrin as substrate does not provide any information on the nature of this debranching activity, these same results could be due to the presence of $u$-amylase activity. This possibility is eliminated by recalling that the $\alpha$-amylase in pea cotyledon extracts is readily and completely inactivated in the presence of EDTA (ref. 3). Furthermore, when the purified $\alpha$-amylase from pea cotyledons was added to preparations tested for debranching activity, the added $a$-amylase was totally inactive under these test conditions whereas debranching activity remained. In addition, no $\alpha$-amylase activity has ever been detected in extracts of pea seedling axis tissues. Consequently, the ability of cotyledon and stem extracts to degrade a $\beta$-limit dextrin must be due to amylopectin-I,6-glucosidase activity. All the necessary enzymes requircd for the breakdown of starch to glucose by simple hydrolytic reactions, therefore, are functional in the pea seedling. 


\section{Phosphorylase activity of pea cotyledons}

Sucrose, however, is usually regarded as the major form of carbohydrate transported within plants. Since phosphorylase has previously been detected in pea seeds ${ }^{4}$, the question remained as to whether starch degradation can also occur in pea seedlings via a pathway utilizing this enzyme and involving sucrose as an intermediate. Studies in this respect were begun by determining the level of phosphorylase activity in extracts of cotyledons germinated for I through Io days (Fig. 4). As can be seen, phosphorylase activity increases rapidly in the cotyledon during germination until about the eighth day; thereafter, the level begins to decline. In contrast, the phosphorylase activity of mung bean steadily declines throughout 7 days of germination ${ }^{18}$. As a first indication, therefore, this enzymic activity could well be of importance for the degradation of starch reserves at some stage of germination of the pea cotyledon.

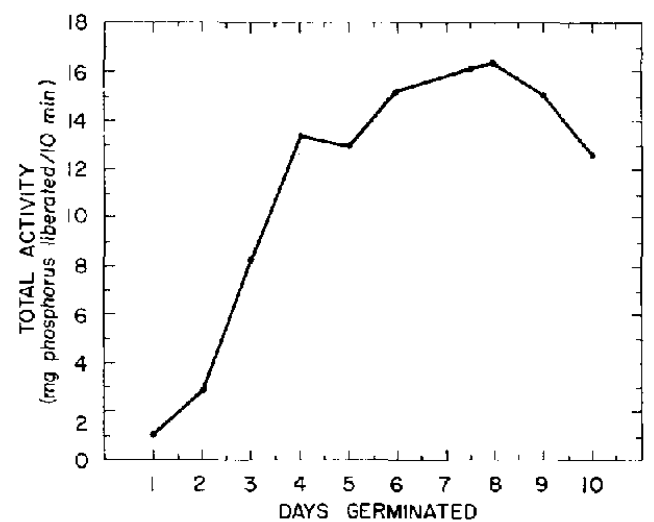

Fig. 4. Phosphorylase activity in pea cotyledons during germination. Enzymic extracts were prepared by homogenizing 30 cotyledons in a Waring blendor, at each day indicated, with $30 \mathrm{ml}$ of $0.05 \mathrm{M}$ acetate buffer solution ( $\mathrm{pH}$ 6.0) containing 0.00 I M EL)' A plus $0.005 \mathrm{M}$ 2-mercaptoethanol. The homogenate was centrifuged for $10 \mathrm{~min}$ at $18000 \times g$, and the supernatant fluid tested for phosphorylase activity. The reaction mixtures were uniformly incubated at $35^{\circ}$.

Studies by Leloir and Cardini ${ }^{19}$ and Bean and Hassid ${ }^{20}$ show that pea seedlings synthesize sucrose by a reaction involving UDPG and $\mathrm{D}$-fructose-6-phosphate. UDPG formation is also known to occur in pea seeds ${ }^{21}$. It would seem, therefore, that the most obvious biochemical role for phosphorylase in germinating pea cotyledons would be to provide the glucose I-phosphate needed for UDPG formation and subsequent sucrose synthesis. Apparently, the glucose I-phosphate formed by phosphorylase activity is not simply hydrolyzed liberating free glucose. In a direct test for such phosphatase activity (EC 3.T.3.Io), we incubated glucose I-phosphate with pea cotyledon extracts and measured the release of inorganic phosphate. No phosphate-releasing activity was detected that could not be accounted for by the action of phosphorylase and starch primer present in the enzymic extract. Further proof for concluding that phosphorylase is the enzyme responsible for the observed phosphate release is the finding that such activity is progressively inhibited when titrated with $\beta$-amylase ${ }^{22}$. A significant level of glucose 6 -phosphatase (EC 3.I.3.9) activity is also absent in cotyledon extracts; the potassium salt of glucose 6-phosphate is not hydrolyzed by such preparations. 
Extracts of pea axis tissue readily hydrolyze sucrose. These extracts were made by homogenizing (Waring blendor) $7.2 \mathrm{~g}$ (wet wt.) of axis tissue from 7 -dayold seedlings with $20 \mathrm{ml}$ of $0.025 \mathrm{M}$ acetate buffer $\left(\mathrm{pH}_{5.4}\right)$. The homogenate was centrifuged for Io min at $18000 \times g$ and the resulting supernatant fluid dialyzed for $\mathrm{I}_{4} \mathrm{~h}$ against $500 \mathrm{ml}$ of $0.025 \mathrm{M}$ acetate buffer $(\mathrm{pH} 5.4)$. When $0.5 \mathrm{ml}$ of this extract was incubated at $33^{\circ}$ with $\mathrm{r} .0 \mathrm{ml}$ of $3 \%$ sucrose solution (final vol. $-2.0 \mathrm{ml}$ ), reducing substances were released (expressed in terms of maltose equivalents; $0.8 \mathrm{mg}$ of maltose per $\mathrm{mg}$ protein per $15 \mathrm{~min}$ ). This hydrolytic activity required the presence of both sucrose and native enzyme; extracts boiled for 2 min were inactive. Glucose and fructose were identified as products of this enzymic reaction as follows. An extract of axis tissue $\left(2.4 \mathrm{mg}\right.$ protein) was incubated for 30 min at $33^{\circ}$ with $0.5 \mathrm{ml}$ of a $6 \%$ sucrose solution (final volume $=\mathrm{I} .5 \mathrm{ml}$ ). After incubation, aliquots of the reaction mixture were applied to Whatman No. I filter paper and the chromatogram developed in a solvent system consisting of ethyl acetate- $n$-butanol acetic acid $\mathrm{H}_{2} \mathrm{O}$ $(8: 3: 3: 2, v / v$, descending solvent flow). Only 2 new substances were detected by the $p$-anisidine spray ${ }^{23}$ corresponding in mobility with known glucose and fructose.

That this enzymic activity is indeed an invertase (EC 3.2. I.26) is further substantiatcd by the finding that the trisaccharide, raffinose [ $O-\alpha$-D-galactopyranosyl$(\mathrm{I} \rightarrow 6)-O-\alpha$-D-glucopyranosyl-(I- $>2)-\beta$-D-fructofuranoside], is hydrolyzed by these same axis tissue extracts whereas the trisaccharide melezitose $\lceil O-\alpha$-D-glucopyranosyl-(I $\rightarrow 3)-O-\beta$-D-fructofuranosyl- $(2 \rightarrow I)-\alpha-D$-glucopyranoside! is not. Thus, the enzyme in question appears to be a $\beta$-fructofuranosidase and not a glucosido-invertase 24 .

Sucrase activity is not present in pea cotyledon extracts. This observation is correlated with the finding that when extracts of pea-seedling tissues are examined for the presence of free sugars (paper chromatographic techniques and the $p$-anisidine spray reagent ${ }^{23}$ ), free sucrose is found in extracts of cotyledons and to a much lesser extent in axis tissue. VITEK ${ }^{25}$ has reported similar results. There is, therefore, good evidence for the operation of a second metabolic pathway for starch degradation in the growing pea seedling. This route requires phosphorylase activity and ultimately yields sucrose as the transportable intermediate. Subsequently, the sucrose is hydrolyzed in the axis tissues with release of fructose and glucose. These findings are similar to those of EdElman, SHibko AND KEys ${ }^{26}$, who found that the scutellum of cereal grains absorbs glucose from the endosperm. The glucose is then converted in the scutellum to sucrose, which sugar is subsequently transported to the seedling.

\section{DISCUSSION}

Evidence is presented showing that two metabolic routes exist in the germinating pea for the degradation of starch reserves to glucose. The one pathway is "phosphorolytic" and involves the following sequence of reactions:

$$
\begin{aligned}
& \text { Starch }+\mathrm{P}_{i} \stackrel{\text { phosphorylase }}{\rightleftharpoons} \text { glucose I-phosphate } \\
& \text { Glucose I-phosphate }+ \text { UTP } \stackrel{\text { UDPG pyrophosphorylase }}{\rightleftharpoons} \text { UDPG }-P_{i} \\
& \text { UDPG }+ \text { - fructose 6-phosphate } \rightleftharpoons \text { sucrose 6-phosphate } \rightarrow \text { sucrose }+P_{i}
\end{aligned}
$$




$$
\text { Sucrose } \stackrel{\beta \text {-fructofuranosidase }}{\longrightarrow} \text { glucose }+ \text { fructose. }
$$

The other is a "hydrolytic" route involving the sequential action of amylases and a glucosidase, as follows:

$$
\begin{aligned}
& \text { Starch } \stackrel{\alpha \text {-amylase }}{\longrightarrow} \text { oligosaccharides } \\
& \text { Soluble } \quad \beta \text {-amylase } \\
& \text { Oligosaccharides } \stackrel{\text { smaltose }}{\longrightarrow} \text { male } \\
& \text { Maltose } \longrightarrow \stackrel{\alpha \text {-glucosidase }}{\longrightarrow} \text { glucose. }
\end{aligned}
$$

The relative importance of these two pathways in vivo is difficult to assess from information obtained from experiments performed in vitro ${ }^{2,27}$. Certainly, the levels of phosphorylase activity present in the cotyledon during the early stages of germination can account for the observed depletion of starch from that storage organ. In analogy with the cereal seeds, this could be the initial major pathway for the conversion of reserve starch to the glucose that is required and eventually metabolized by the developing seedling. The hydrolytic route, however, may very well assume a rolc of increasing importance during the later stages of germination, since phosphorylase activity begins to decline at about the eighth day (Fig. 4) whereas $\alpha$-amylase continues to increase in activity beyond this time*.

All of the hydrolytic enzymes are present in cotyledon extracts and would, therefore, seem to participate in the process of starch degradation by this organ. Moreover, since the magnitude of $\beta$-amylase activity is much greater in axis tissue than in the cotyledon, it is also likely that any oligosaccharides formed by $\alpha$-amylolysis and capable of being translocated to axis tissue are preferentially degraded to glucose in this tissue. The extent of oligosaccharide digestion in axis tissue, however, is difficult to evaluate since neither the quantity and type of oligasaccharide released by the $\alpha$-amylase nor what hydrolytic products are translocated are known precisely at any given time. Examination of pea stem exudates by paper chromatographic techniques does show a variety of reducing substances, some of which may be small quantities of oligosaccharides. However, no appreciable accumulation of these substances can be anticipated because of the strong $\beta$-amylase activity present in axis tissue. This situation is analogous to that reported by VITEK ${ }^{25}$; he detected little or no sucrose in pea stem extracts, presumably because of the invertase activity found in that tissue, whereas large quantities of glucose are present.

Certainly, the $\alpha$ - and $\beta$-amylases acting in concert are capable of catalyzing extensive hydrolysis of starch. Of the several enzymes involved in the hydrolytic route, the maltase activity is at least an order of magnitude lower than either of the amylase activities. The relationship between the functional levels of $\beta$-amylase and maltase activities in pea seedlings appears to be rather widespread in plants ${ }^{28}$. When one considers the energy required for sucrose synthesis, the most economical route for starch breakdown would be the "phosphorolytic" pathway since the energy of the glucosidic bond is retained. The role of the $\alpha$-amylase might then be to enhance this reaction by exposing a larger number of non-reducing end groups. In any event,

'R. R. Swain and E. E. Dekkek, unpublished data. 
the $\beta$-amylase and $\alpha$-glucosidase must represent means of degrading soluble oligosaccharides that are released into the vascular system of the plant as a result of $\alpha-$ amylolysis.

Finally, it should be mentioned that although the observations reported here have been made with the use of etiolated plants, essentially the same results have been obtained with plants grown in a normal day-night cycle.

\section{ACKNOWLEDGEMENT}

This investigation was supported in part by a grant from the National Institute of Arthritis and Metabolic Diseases, United States Public Health Service (Grant AM-037 I8).

\section{REFERENCES}

I E. W. Sutherland and C. F. Cori, J. Hiol. Chem., i 72 (I948) 737 .

2 W. J. Rutter and IR. W. Brosemer, J. Biol. Chem., 236 (ig6r) 1247.

3 R. R. Swain and E. E. Dekker, Biochim. Biophys. Acta, 22 (I966) 75.

4 C. S. Hanes, Proc. Roy. Soc. London, Ser. B. I 28 (1940) $42 \mathrm{I}$.

5 W. J. Whielan, in S. P. Colowick and N. O. Karlax, Methods in Enzymology, Vol. I, Academic Press, New York, 1955, P. 192.

6 O. H. Lowry, N. J. Rosebrough, A. L. Farr and R. J. Randali, J. Biol. Chem., I93 (I951) 265 .

7 H. T. Gordon, W. Thornbukg and L. N. Werum, Anal. Chem., 28 (1956) 849.

8 P. BERNFELD, in F. F. NorD, Advances in Enzymology, Vol. I2, Interscience Publishers, New York, I95I, p. 379 .

9 D. French, in P. I). Boyer, II. Iardy and K. Myran̈ck, The Enzymes, Vol. 4, Academic Press, New York, and edition, I960, p. 345.

io K. H. Mever, P. F. Sfahr and E. H. Fischer, Helv. Chim. Acta, 36 (1953) 1924.

I I X. Jono, Chem. Zentr., I (1932) I IO3.

I2 B. M. Laws and J. H. Moore, Can.J. Biochem. Physiol., 4I (1963) 2107.

I3 D. Keilin ANd E. F. Hartree, Biochem. $J ., 42$ (I948) 221.

I4 V. N. Nigam and K. V. Giri, J. Biol. Chem., 235 (I960) 947.

I. M. Abuullah and W. J. Whelan, Biochem. $J ., 75$ (I960) I 2 P.

16 P. N. Hobson, W. J. Whelan and S. Peat, J. Chem. Soc., (I95I) 14.51.

I7 I. C. MAcwili.inM, Nature, I 8 I (I9.58) I I 43.

I 8 A. Kasugnt, J.Agr. Chem. Soc.Japan, I2 (1963) $76 \mathrm{r}$.

ig L. Ii. Leloir and C. E. Cardini, J. Biol. Chem., 2 I4 (I955) I 57.

20 IR. (. Bean and W. Z. Hassid, J. Am. Chem. Soc., 77 (1955) 5737.

2 I D. H. Turner and J. F. Turner, Biochem. J., 69 (T9.58) 448.

22 H. K. PORTER, Biochem. J., 47 (1950) 476.

23 L. Hough, J. K. N. Jones and W. H. Wadman, J. Chem. Soc, (1950) i 702.

24 K. Myrbäck, in P. D. Boyer, H. Lardy and K. MYrbäck, The Enzymes, Vol. 4, Academic Press, New York, and exlition, I960, p. 379.

25 V. VIтE K, Biochim. Biophys. Acta, 93 (1964) 429.

26 J. Edelmay, S. I. Shibko and A. J. Keys, J. Exptl. Boluny, 1 o (1959) I 78.

27 H. N. Torres and J. M. Olavarria, J. Biol. Chem., 239 (I964) 2427.

28 W. J. WHELAN, Nature, 190 (rg6I) 954.

Biochim. Biophys. Acta, I22 (1966) 87 roo 